\title{
Decreased expression of the GLP-1 receptor after segmental artery injury in mice
}

\author{
Katrine Dahl Bjørnholm 101,2, Gro Klitgaard Povlsen³, Maria Elm Ougaard ${ }^{4}$, Charles Pyke ${ }^{4}$, Günaj Rakipovski², \\ Pernille Tveden-Nyborg', Jens Lykkesfeldt ${ }^{1}$ and Gry Freja Skovsted ${ }^{1}$
}

1Section of Experimental Animal Models, Department of Veterinary and Animal Sciences, University of Copenhagen, Frederiksberg, Denmark 2Department of Cardiovascular Disease Research, Novo Nordisk, Måløv, Denmark

${ }^{3}$ Department of Diabetes Pharmacology 1, Novo Nordisk, Måløv, Denmark

${ }^{4}$ Department of Pathology and Imaging, Novo Nordisk, Måløv, Denmark

Correspondence should be addressed to K D Bjørnholm: katrine@dahlbjornholm.dk

\begin{abstract}
The glucagon-like peptide-1 receptor (GLP1R) is expressed in the renal vasculature and known to be downregulated under hypertensive conditions in rats and humans. However, little is known about the regulation in other types of renal pathology involving vascular changes. This study investigates the expression of the GLP1R in renal vasculature after glomerular injury in the nephrotoxic nephritis mouse model, high cholesterol, and atherosclerosis in the Ldlr-/- mouse on Western diet, and ex vivo injury in an organ culture model. The immunohistochemical signal of the GLP1R was significantly decreased in arteries from mice with nephrotoxic nephritis after 42 days compared to 7 days and saline control $(P<0.05)$. Histological evaluation of kidneys from $L d / r$-/- mice on Western diet showed a decreased GLP1R specific immunohistochemical signal $(P<0.05)$. The dilatory response to liraglutide was decreased in Western diet fed $L d l r-/-$ mice compared to $C 57 \mathrm{Bl} / 6 \mathrm{~J}$ controls $(P<0.05)$. Organ culture significantly decreased the immunohistochemical signal of the GLP1R $(P<0.05)$ and the expression of Glp1r mRNA $(P<0.005)$ compared to fresh. Organ cultured vessels showed vascular smooth muscle cell remodelling as Acta2 expression was decreased $(P<0.005)$ and Ednrb was increased $(P<0.05)$. In conclusion, nephrotoxic nephritis and hypercholesterolaemia led to decreased GLP1R specific immunohistochemical signal. Ex vivo vascular injury in the organ culture model leads to a decrease in expression of GLP1R expression and contractile VSMC specific markers and increase in expression of dedifferentiation markers suggestive of an inverse relationship between phenotypic switch of the VSMC and the expression of the GLP1R; however, the causal relationship remains elusive.
\end{abstract}

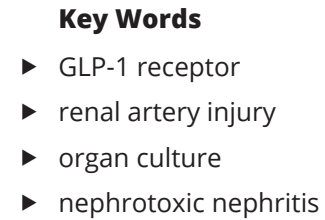

Journal of Endocrinology (2021) 248, 289-301

\section{Introduction}

Kidney disease has serious impact on quality of life for patients and confers severe costs on health care systems (Luyckx et al. 2018). Acute kidney disease is often caused by conditions such as glomerulonephritis, volume depletion, and toxic insults. Acute disease may progress to chronic kidney disease (Chawla \& Kimmel 2012, Alscher et al. 2019). Additional risk factors for development of chronic kidney disease include diabetes, metabolic disease, and hypertension (Briet \& Burns 2012). The initial phase of kidney disease or injury involves changes in the renal vasculature including loss of capillaries (Choi et al. 2000, Horbelt et al. 2007). Ischaemia and resulting 
activation of inflammatory pathways induce fibrosis and the transition into a chronic stage injury (Yuan et al. 2003, Humphreys et al. 2010). Vascular smooth muscle cells (VSMC), endothelial cells, and pericytes in the renal vasculature react to stimuli such as sustained increased blood pressure or persistent inflammation by vascular remodelling including dedifferentiation of VSMC (Eberhardt \& Pfeilschifter 2007, Briet \& Burns 2012). In recent years, clinical and preclinical studies have indicated beneficial effects of treatment with long acting GLP-1 receptor (GLP1R) agonists on renal (Moreno et al. 2002, Yu et al. 2003, Bisgaard et al. 2016, Mann et al. 2017) and cardiovascular disease (Marso et al. 2016ab). GLP-1 is a gut derived peptide hormone released upon a carbohydrate rich meal to the blood stream where it is rapidly broken down by dipeptidyl peptidase IV resulting in a half-life in plasma of approximately 2 min (Holst 2007). The peptide activates GLP1R in several tissues including, but not limited to, the pancreas, ventricle, and the CNS where it leads to insulin secretion, reduces gastric motility, and induces satiety, respectively (Doyle \& Egan 2007, Holst 2007, Shah \& Vella 2014). In the kidney, GLP1R is expressed in small and larger renal arteries where it is located on the VSMC (Pyke et al. 2014, Richards et al. 2014, Jensen et al. 2015) in both mouse and man (Korner et al. 2007, Pyke et al. 2014, Richards et al. 2014). However, the function of the GLP1R in the renal vasculature is yet to be fully understood. Studies in rodents have shown that stimulation of the renal GLP1R increases renal blood flow and perfusion, induces vasodilation of afferent arterioles, increases glomerular filtration rate, and increases diuresis and natriuresis (Moreno et al. 2002, Jensen et al. 2015, Katsurada et al. 2019). In humans, treatment with GLP1R agonists have been reported to induce a marginal decrease in systemic blood pressure (Marso et al. 2016ab). In healthy men it decreases angiotensin II secretion and aldosterone blood levels - components of the renin-angiotensin-aldosterone system, potentially indicating beneficial effects of GLP-1 on hypertension (Skov et al. 2013). Regulation of GLP1R expression during disease has previously been shown in the thoracic aorta of diabetic mice (Kimura et al. 2017) and renal vasculature of spontaneously hypertensive rats and humans (Liu et al. 2015, Ronn et al. 2017), suggesting a relationship between the pathophysiology associated with hypertension and the expression of the GLP1R. However, whether expression of the GLP1R in renal vasculature is affected by other pathological conditions has not been fully elucidated. Effects of metabolic diseases, low-grade inflammation and vascular injury on the expression and/or function of the GLP1R can be important for regulation of kidney perfusion, blood pressure and glomerular filtration rate regulation, and it may play a role in kidney tissue integrity (Fujita et al. 2014, Thomas 2017). A detailed pathophysiologic understanding of the GLP-1 system in the kidneys will provide valuable insight into the mode of action of GLP1R agonists in renal injury and vascular disease.

This study investigates the change in GLP1R specific immunohistochemical signal in the renal segmental arteries (SA) under three different conditions involving vascular pathology: the nephro-toxic nephritis model (NTN), where an immune reaction to the glomerular basement membrane leads to renal vascular pathology (Ougaard et al. 2018b), the Ldlr-/- mouse fed a WD diet where hypercholesterolaemia and metabolic syndrome leads to atherosclerosis (Ishibashi et al. 1993, Ma etal. 2012), and an ex vivo over-night organ culture model mimicking acute vascular injury (De Mey et al. 1989). Furthermore, real-time qPCR was employed to investigate the effect of organ culture on transcription of the Glp1r gene and genes related to VSMC differentiation in SA. Lastly, the change in isometric tension after stimulation with the long acting GLP1R agonist, liraglutide, was investigated in the $L d l r-/$ - model and in the organ culture model using wire myography. It was hypothesized that the GLP1R expression and function is affected by renal vascular injury resulting in decreased GLP1R-specific immunosignal, down regulation of Glp1r mRNA and concurrent changes in vasodilatory response of the SA to liraglutide.

\section{Materials and methods}

\section{Animal studies}

The study was approved by the Danish Animal Experiments Inspectorate under the Ministry of Environment and Food and carried out by trained and licensed personnel. All animals were kept in $12 \mathrm{~h}$ light : $12 \mathrm{~h}$ darkness cycle with access to water and chow diet ad libitum (Altromin \#1324, Brogaarden, Lynge, Denmark) except one Ldlr-/- group that received Western diet $(n=12$, D12079R, Research diet, New Brunswick, NJ, USA) ad libitum for 21 weeks. Temperature and humidity were maintained at $22 \pm 2^{\circ} \mathrm{C}$ and $50 \pm 20 \%$, respectively. Group sizes were chosen based on results from previous experiments.

\section{Nephrotoxic nephritis (NTN)}

NTN was induced in female CD1 mice (Charles River) by i.v. injection with sheep serum containing antibodies 
towards mouse glomerulus components as previously described (Ougaard et al. 2018a). NTN mice were sacrificed at days $7(n=5)$ and $42(n=5)$ post serum injection. A PBS injected healthy control was euthanized at day 42 $(n=5)$. Mice were anaesthetized with isoflurane, and once fully anaesthetized a laparotomy was performed by abdominal midline incision, and the thoracic cavity was exposed by cutting along the sternum. Animals were perfused with $0.9 \% \mathrm{NaCl}$ with heparin $(10 \mathrm{U} / \mathrm{mL})$ through the heart. Kidneys were carefully isolated and collected after perfusion and placed in $4 \%$ formalin (Hounisen, Skanderborg, Denmark) for histologic examination (see subsequently).

\section{LdIr-/- mice on WD}

The effect of hypercholesterolaemia on vascular inflammation was investigated in the Ldlr-/- mice (B6.129S7-Ldlrtm1Her/J, Stock \#02207, Jackson labs JAX) fed chow diet $(n=11)$ or WD $(n=11)$ for 21 weeks. A parallel group of healthy chow fed age matched C57BL/6J (Taconic, Lille Skensved, Denmark, $n=10$ ) controlled for effect of age on vascular change. The mice were anaesthetized by s.c. injection with $0.5-0.8 \mathrm{~mL}$ hypnorm (fentanyl, $0.315 \mathrm{mg} / \mathrm{mL}$ and fluanisone $10 \mathrm{mg} / \mathrm{mL}$; VetaPharma Limited, Leeds, United Kingdom) and midazolam $(5 \mathrm{mg} / \mathrm{mL}$, Accord Healthcare Limited, Middlesex, United Kingdom) mixed with sterile water 1:1:2, respectively. Once anaesthetized animals were opened as described previously and perfused by a gentle injection of approximately $10 \mathrm{~mL}$ ice-cold saline (Fresnius Kabi, Sèvres Cedex, France, pH 6) into the left ventricle. Immediately after perfusion the right kidney was isolated and placed in ice-cold MOPS buffered saline $(5 \mathrm{mM}$ $\mathrm{KCl}, 145 \mathrm{mM} \mathrm{NaCl}, 1 \mathrm{mM} \mathrm{KH} \mathrm{PO}_{4}, 1 \mathrm{mM} \mathrm{MgSO} \cdot 7 \mathrm{H}_{2} \mathrm{O}$, $2.5 \mathrm{mM} \mathrm{CaCl}$, and $5 \mathrm{mM}$ glucose, $1 \%$ albumin from Sigma, and $2 \mathrm{mM}$ NaPyruvate from Gibco, adjusted to
$\mathrm{pH} 7.4$ at $4^{\circ} \mathrm{C}$ ) for dissection and myograph investigation. The left kidney was halved in the transverse plane and placed in $4 \%$ formalin (Hounisen, Skanderborg, Denmark) for histological examination.

\section{Termination of mice for organ culture}

All mice for organ culture were acclimatized for 5 days before they were picked in random order and euthanized by cervical dislocation, and kidneys were collected and placed in ice-cold MOPS buffered saline for dissection of the SA. The organ culture experiment comprises three sub-experiments. First, the acute change in Glp1r mRNA transcription, contractile VSMC marker $\alpha$-smooth muscle cell action (Acta2), and VSMC dedifferentiation marker $\mathrm{ET}_{\mathrm{B}}$ receptor $(E d n r b)$ was investigated in a 6-h organ culture of SA from naïve C57BL/6J mice (Taconic, Lille Skensved, Denmark) by qPCR analyses ( $n=8$, see details subsequently). Secondly, the effect of $24-\mathrm{h}$ organ culture on the response of the $\mathrm{SA}$ to the $\mathrm{ET}_{\mathrm{B}}$ receptor specific agonist, sarafotoxin 6c (S6c), and the response to cumulative concentration of the long acting GLP1R agonist, liraglutide, was investigated in Glp1r-/- mice $(n=8)$ and WT littermates $(n=8)$. Glp1r-/-, and corresponding WT mice were custom bred by Taconic, Lille Skensved Denamrk, as described previously (Scrocchi et al. 1996). The background strain was C57Bl6/J.

Table 1 gives an overview of the different mice used for the three separate experimental setups in the present study.

\section{Dissection and isometric force measurements of segmental arteries}

The isolated kidneys were cleared from surrounding tissue, and the capsule was removed. SAs were dissected by cutting the kidney in half in the coronal plane so that the

Table 1 Mouse strain specifications.

\begin{tabular}{|c|c|c|c|c|c|c|c|}
\hline Strain & Exp. setup & Age at termination & Total, $n$ & Feed & Housing & Gender & Euthanasia \\
\hline CD1 & NTN & 15-16 weeks & 15 & Chow & 8/box & Female & $\begin{array}{l}\text { Inh. anaesthesia and } \\
\text { saline perfusion }\end{array}$ \\
\hline$L d / r-/-1$ & $\begin{array}{l}\text { Extra renal vascular } \\
\text { inflammation }\end{array}$ & 46 weeks & 22 & Chow or WD & Single & Male & $\begin{array}{l}\text { Inj. anaesthesia and } \\
\text { saline perfusion }\end{array}$ \\
\hline C57BL/6J AM & $\begin{array}{l}\text { Extrarenal vascular } \\
\text { inflammation }\end{array}$ & 42 weeks & 10 & Chow & 8/box & Male & $\begin{array}{l}\text { Inj. anaesthesia and } \\
\text { saline perfusion }\end{array}$ \\
\hline $\begin{array}{l}\text { Naïve } \\
\text { C57Bl/6] }\end{array}$ & Organ culture & 9-13 weeks & 32 & Chow & 8/box & Male & $C D$ \\
\hline Glp1r-/- & Organ culture & Appx 20 weeks & 8 & Chow & Single & Male & CD \\
\hline Glp1r WT & Organ culture & Appx 20 weeks & 8 & Chow & Single & Male & $C D$ \\
\hline
\end{tabular}

Appx, approximately; CD, cervical dislocation; Inh., inhalation; Inj, injection; NTN, nephrotoxic nephritis.

https://joe.bioscientifica.com

https://doi.org/10.1530/JOE-20-0608 (c) 2021 Society for Endocrinology Published by Bioscientifica Ltd. Printed in Great Britain 
papilla and the pelvis of the kidney could be visualized. Following removal of the papillae and the segmental vein, one or two SAs were dissected and cut into segments of 1.5-2 mm length. Two $15 \mu \mathrm{m} \mathrm{W}$ wires (DMT, Århus, Denmark) were carefully introduced through the lumen of the vessel, and the SA was mounted in the myograph bath (M620, DMT, Århus, Denmark) in pre gassed $\left(5 \% \mathrm{CO}_{2}\right.$ and $95 \% \mathrm{O}_{2}$ ) ice-cold physiological saline solution (PSS, $4.7 \mathrm{mM} \mathrm{KCl}, 119 \mathrm{mM} \mathrm{NaCl}, 20 \mathrm{mM} \mathrm{NaHCO}_{3}$, $1.2 \mathrm{mM} \mathrm{KH} \mathrm{PO}_{4}, 1.2 \mathrm{mM} \mathrm{MgSO} \cdot 7 \mathrm{H}_{2} \mathrm{O}, 2.5 \mathrm{mM} \mathrm{CaCl}$, and $5 \mathrm{mM}$ glucose, $0.02 \mathrm{mM}$ EDTA from Sigma). After mounting the PSS was changed to pre warmed $\left(37^{\circ} \mathrm{C}\right)$ and pre gassed $\left(5 \% \mathrm{CO}_{2}\right.$ and $\left.95 \% \mathrm{O}_{2}\right)$ PSS, and the baths were kept at a controlled temperature at $37^{\circ} \mathrm{C}$ and were continuously gassed with $5 \% \mathrm{O}_{2}$ and $95 \% \mathrm{CO}_{2}$.

After mounting, the SAs were normalized to $90 \%$ of the internal circumference that the vessel would have had after application of a transmural pressure of $100 \mathrm{mmHg}$, using the DMT normalization module for Lab Chart (AD Instruments, Bella Vista, Australia). Following 40 min equilibration all vessels were subjected to a wakeup protocol of three consecutive potassium responses using 63 $\mathrm{mM} \mathrm{KCl}$ PSS $\left(63 \mathrm{mM} \mathrm{KCl}, 55.5 \mathrm{mM} \mathrm{NaCl}, 20 \mathrm{mM} \mathrm{NaHCO}_{3}\right.$, $1.2 \mathrm{mM} \mathrm{KH}_{2} \mathrm{PO}_{4}, 1.2 \mathrm{mM} \mathrm{MgSO} \cdot 7 \mathrm{H}_{2} \mathrm{O}, 2.5 \mathrm{CaCl}_{2}$ all from Merck, and $5 \mathrm{mM}$ glucose, $0.02 \mathrm{mM}$ EDTA from Sigma). A threshold of $0.5 \mathrm{mN} / \mathrm{mm}$ constriction in the last $\mathrm{KCl}$ response was the inclusion criteria through all myograph experiments. The following agents were used to produce concentration response curves: phenylephrine (PE, 10-10-10-4M, Sigma, stock solution $0.1 \mathrm{M}$ in Milli-Q), sarafotoxin6c (S6c, 10-7M, Tocris, Abingdon, UK, stock solution $0.1 \mathrm{M}$ in in $0.1 \%$ human serum albumin). For preconstrictions and time control curves a fixed concentration of PE 10-6 M was used (Sigma, stock solution 0.1 Min Milli-Q). Dilatory substances were added to the pre-constricted vessels to assess endothelium dependent vasodilation by acetylcholine (Ach, $10^{-10}-10^{-4} \mathrm{M}$, Sigma, stock solution $0.1 \mathrm{M}$ in Milli-Q) and endothelium independent NO mediated vasodilation by sodium nitroprusside (SNP, $10^{-10}-10^{-5} \mathrm{M}$, Sigma, stock solution $0.1 \mathrm{M}$ in Milli-Q). All stocks were kept at $-20^{\circ} \mathrm{C}$. For studies of GLP1R mediated dilation by liraglutide in $0.007 \%$ polysorbate $20,50 \mathrm{mM}$ $\mathrm{PO}_{4}, 70 \mathrm{mM} \mathrm{NaCl}$ and Milli-Q water (stock concentration $1 \mu \mathrm{M}$ and kept at $4^{\circ} \mathrm{C}$, Novo Nordisk $\mathrm{A} / \mathrm{S}$ ), human serum albumin was added to buffer to reach concentration of $0.1 \%$, and vessel was allowed to stabilize before liraglutide was added in accumulating doses with at exactly $7 \mathrm{~min}$ intervals $\left(10^{-11}-10^{-5} \mathrm{M}\right)$. Prior to the liraglutide concentration response a 42 min time control was run on each artery to control for variation in the PE pre-construction during the very long liraglutide response. After the time control, the artery was washed thrice and allowed to rest for $30 \mathrm{~min}$ before pre-constricting with $10^{-10} \mathrm{M} \mathrm{PE}$ for the liraglutide concentration response. The time control curve change in tension from initial preconstriction corresponding to each time point in the liraglutide concentration response was subtracted the liraglutide response.

\section{Organ culture}

For organ culture experiments, a second segment was dissected from the animal from which the fresh vessel was isolated. The segment was mounted onto one $15 \mu \mathrm{m} \mathrm{W}$ wire and transferred to a 24 well plate with $1 \mathrm{~mL}$ serum free medium DMEM (DMEM1X+GlutaMAX ${ }^{\mathrm{TM}}, 1 \mathrm{~g} / \mathrm{L}$ Glucose,+pyruvate, Gibco life technologies) mixed with Pen Strep (penicillin $100 \mathrm{IU} / \mathrm{mL}$, streptomycin $100 \mu \mathrm{g} / \mathrm{mL}$, respectively, Gibco Life technologies). Plates were placed in incubator of $37^{\circ} \mathrm{C}$ with humidified $5 \% \mathrm{CO}_{2}$ in air for $24 \mathrm{~h}$ $(+/ 1 \mathrm{~h})$. OC vessels were mounted the following day on a second wire in the myograph baths in preheated $\left(37^{\circ} \mathrm{C}\right)$ and pre gassed ( $5 \% \mathrm{CO}_{2}, 95 \% \mathrm{O}_{2}$ for $\left.20 \mathrm{~min}\right)$ PSS and subjected to a protocol identical to the fresh vessel experiment to ensure pairing of the two vessels from the same animal.

\section{qPCR}

For mRNA expression of segmental arteries in organ culture, RNA was isolated from collected SAs by phase separation with trizol (15596026, Ambion) and 1-bromo3 chlorpropane (1-BCP, Sigma). RNA was extracted from the aqueous phase using the RNeasy micro kit (Qiagen). RNA concentration was analysed by NanoDrop 8000 system (Thermo Fisher Scentific). cDNA was prepared by iScript cDNA synthesis kit (BioRAd). qPCR was run on $2.5 \times$ diluted cDNA using Taqman Fast Advanced Master mix (PN 4444557, Life Technologies) and Taqman Gene Expression Assays for the three genes coding for the GLP1R, Glp1r (Mm00445292_m1). The effect of OC on VSMC dedifferentiation and differentiation was investigated by regulation of the $\mathrm{ET}_{\mathrm{B}}$ receptor coded for by Ednrb (Mm00432989_m1), which was used as a marker of VSMC dedifferentiation and the contractile SMC marker aSMA coded for by Acta2 (Mm00725412_s1) as marker of differentiated VSMC. Actin beta (Actb, Mm02619580_g1) was used as reference gene (All from Life Technologies).

\section{Immunohistochemistry}

Fixed kidneys were halved in the transverse plane, dehydrated, and embedded in paraffin. For preparation 
of dissected SAs the arteries were first embedded in 3\% Bacto $^{\mathrm{TM}}$ Agar (BD Diagnostics, Franklin Lakes, New Jersey, USA), dehydrated, and embedded in paraffin for microtome sectioning $(4.5 \mu \mathrm{m})$. Sections were stained with haematoxylin eosin (HE) according to standard procedures. Immunohistochemical stains were performed using the Ventata Discovery XT automation system (Ventana Inc., Roche), and the Rb-GLP1R antibody $(2.7 \mu \mathrm{g} / \mathrm{mL}$, ab218532 Abcam) labelled using the DISCOVERY purple chromogen kit (ref: 760-229, Roche). Please refer to Supplementary Fig. 4 (see section on supplementary materials given at the end of this article) for specificity to the mouse GLP1R. An identical protocol without primary antibody was run in parallel as negative control on an adjacent level to the level stained for GLP1R. The ratio of immunohistochemical stain area per arterial cross section area was quantified using the HALO software as previously described (Koelzer et al. 2018) and shown in per cent of vessel wall area (algorithm: Area of Quantification version 2.31, Indica Labs, Albuquerque, USA). To standardize vessel type and size and ensure comparability to the SA isolated after myograph, a subset of arteries from whole kidney sections (3-10 per kidney dependent on availability on specific section) were selected. As diameter could be affected by disease and technical circumstances after myograph mounting, the diameter of the vessel selection based on diameter might introduce bias. Consequently, the anatomical selection criterion of the relevant arteries was that the muscularized artery was located adjacent to a vein and not surrounded by perivascular adipocytes corresponding to the SA or the first branch hereof (A. interlobare). The positive immunohistochemical staining is given as a ratio of the cross section of that specific vessel. The results of one mouse represents the mean ratio of all analysed arteries in one cross-sectional level. All image analyses were carried out in a blinded fashion.

\section{Modelling and statistics}

All data are presented as mean \pm S.E.M. Data were analysed using GraphPad Prism version 8 (Graph Pad). Outliers were identified using the ROUT test and removed (one outlier was removed based on this test) (Motulsky \& Brown 2006). For statistical analyses, values of $P<0.05$ were considered significant. Normal distribution of data was tested with Shapiro Wilk's test, in case data were not normally distributed a non-parametric test was used as follows: for comparisons between two groups Student's $t$-test or Wilcoxon paired rank test were applied for parametric and non-parametric data, respectively.
For comparisons between more than two groups an Ordinary One-Way ANOVA followed by Tukey's multiple comparison test or Kruskal-Wallis test followed by Dunn's multiple comparisons test was applied for parametric and non-parametric distributions, respectively. Organ culture data were considered paired as fresh and organ culture vessel originated from the same animal.

\section{Results}

\section{GLP1R immunohistochemical detection in NTN model} of renal injury

Representative images of immunohistochemistry (IHC) of GLP1R in NTS dosed CD1 mice are displayed in Fig. 1A, B, C, D, E and F. NTS led to changes in renal tissue architecture characterized by lack of glomerulus tubule structure, interstitial tissue oedema and infiltration with inflammatory cells, the vascular wall thickness was increased at 42 days post-NTS injection (Fig. 1A, B, C, D, E, F and Supplementary Fig. 1). GLP1R positive signal was observed in the VSMC, whereas the endothelium and remaining structures in the kidney that is, tubules, interstitium and calyces were negative of IHC signal. A time dependent decrease in GLP1R specific signal in the vessel wall was observed with most pronounced reduction of the signal 42 days after injection of NTS (Fig. 1B, D and F). No positive stain was detected in the vasculature of the negative control (Fig. 1G). Semiquantitative analyses of the IHC signal in the arteries showed a time dependent decrease of the GLP1R specific signal in the renal arteries (Fig. 1H) with a significant difference between controls and NTS at 42 days $(P=0.0054)$ and between 7 and 42 days post NTS injection $(P=0.0460)$.

\section{GLP1R detection and function in LdIr-/- mouse model}

Renal tissue from C57Bl/6J AM and Ldlr-/- chow fed animals showed intact architecture and positive detection of GLP1R signal (Fig. 2A and B). Kidneys of WD fed mice showed marked perivascular accumulation of inflammatory cells in 5 out of the $11 \mathrm{Ldlr}$-/- mice on WD (Fig. 2C and Supplementary Fig. 2). Negative controls, without primary antibody showed no positive stain (Fig. 2D). Arteries of kidneys from Ldlr-/- mice on WD showed a significant decrease in GLP1R specific staining intensity compared to age matched C57BL/6J (Fig. 2E, $P=0.0404$ ) and a tendency to a decreased staining compared to chow fed $L d l r-/$ - animals (Fig. 2E, $P=0.136$ ). 


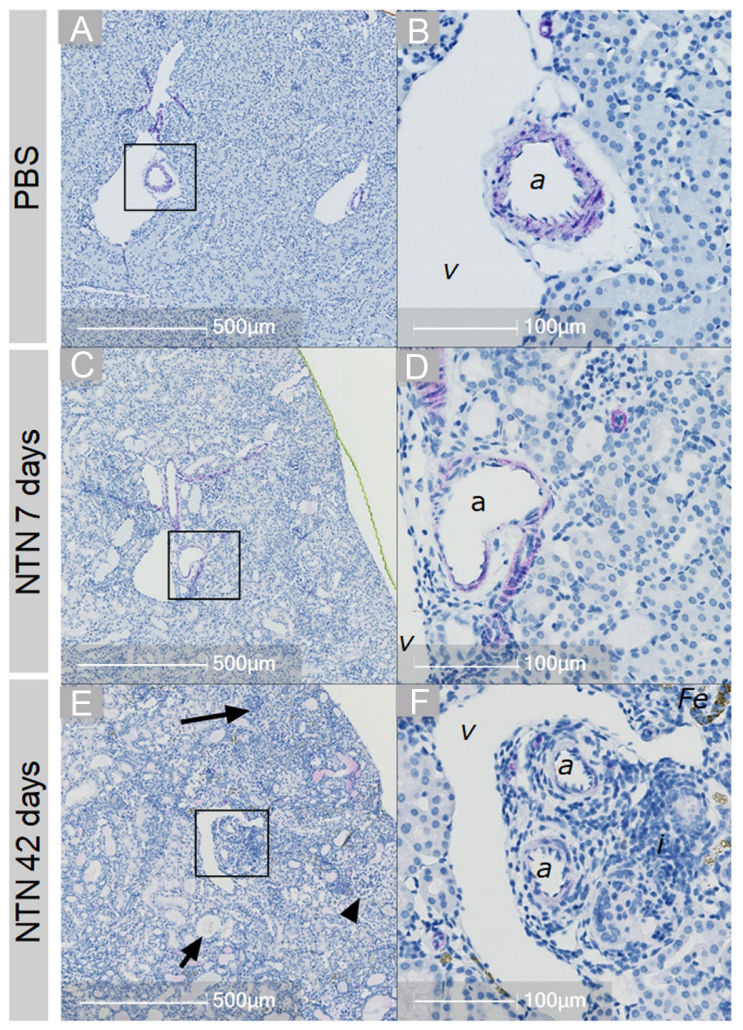

$\mathrm{H}$

\section{NTN GLP1R IHC}

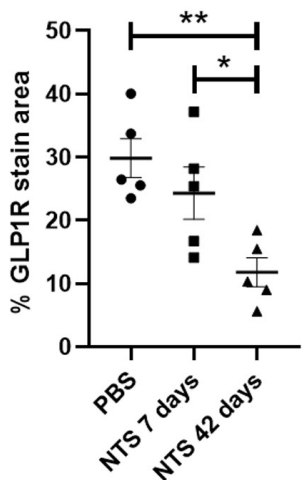

\section{Figure 1}

Results of immunohistochemical detection of GLP1R in NTN mice. (A, B, C, D, E and F) Representative images of GLP1R IHC from healthy PBS injected animals (top row), 7 days after injection of NTS (second row), and 42 days after NTS injection (third row). In each panel: first column 10x magnification of kidney tissue architecture, scale bars $500 \mu \mathrm{m}$. Second column $40 \times$ magnification of black square, scale bars $100 \mu \mathrm{m}$. Arrowhead, loss of regular glomerulus structure, short arrow: interstitial oedema, long arrow: infiltration with inflammatory cells. (G) 40x magnification of negative control. $a$, artery; $v$, vein; $\mathrm{Fe}$, iron sediments in tubules; $i$, perivascular inflammatory cells. (H) Results of image analysis of area of quantification of selected arteries from kidney preparation from PBS $(\bullet, n=5)$ or NTS injected mice at days $7(\boldsymbol{\square}, n=5)$ and $42(\boldsymbol{\Lambda}, n=5)$ after injection. Individual values represent mean of 3-9 arteries per mouse. Data shown as individual values, mean and S.E.M. Ordinary One-Way ANOVA, Tukey's post hoc analysis. $\star P<0.05, * * P<0.005$
There were no differences in vasomotor responses to $63 \mathrm{mM} \mathrm{KCl}, \mathrm{PE}, \mathrm{Ach}$, and SNP or passive diameter of the SA between the three groups (Table 2 and Supplementary Fig. 3). WD fed animals had significantly higher bodyweight, higher blood cholesterol, and blood triglycerides. These results are published elsewhere (Bjørnholm et al. 2020). Liraglutide exposure (10-6 M) induced a vasodilatory response on PE pre-constricted vessels. The dilatory response to 10-6 M liraglutide was significantly attenuated in SA from Ldlr-/- mice on WD compared to C57BL/6J aged-matched controls (Fig. 2F, $P=0.0419)$.

\section{Effect of organ culture on GLP1R gene expression, immunohistochemical staining and function}

Fresh vessels were characterized by a strong stain of GLP1R in the vessel wall (purple, Fig. 3C) and organ cultured exhibited a lower GLP1R immunoreactivity (Fig. 3D). Quantification of the stain area ratio (of vessel wall cross section) resulted in a significant decrease of GLP1R specific immunoreactivity after $24 \mathrm{~h}$ organ culture (Fig. 3E, $P=0.0213$ ). Organ culture of $6 \mathrm{~h}$ led to significant downregulation of Glp1r gene expression compared to fresh vessels (Fig. $3 \mathrm{~F}, P=0.0006$ ). Liraglutide induced a concentration dependent relaxation of pre-constricted
SA from WT mice whereas the relaxation was absent in Glp1r-/- mice confirming that the relaxation was mediated by a GLP1R specific mechanism both in fresh and organ cultured vessels (Fig. 4A and B). Trace graphs of the liraglutide response (Fig. 4A and B, respectively) showed a highly variable and oscillating nature of the liraglutide response in organ culture SA compared to fresh, where the response was consistent and uniform. Thus, whereas the vasodilatory response to liraglutide appears to be qualitatively changed after organ culture attaining a much more oscillatory nature than in fresh SA, the oscillatory nature of the liraglutide responses after organ culture prevented quantitative comparisons between the magnitude of the response in fresh vs organ cultured SA.

\section{Effect of organ culture on VSMCs phenotypic switch}

Organ culture of segmental arteries from naïve C57BL/6J mice induced significant increase in expression of the $\mathrm{ET}_{\mathrm{B}}$ receptor (Ednrb, Fig. 5A, $P=0.0313)$ and a significantly lower expression of the contractile smooth muscle cell marker Acta2 (Fig. 5B, $P=0.0018$ ), suggesting a shift to a dedifferentiated VSMC phenotype in the organ cultured vessels. Fresh SA from Glp1r-/- showed a significantly larger contractile response to the selective $\mathrm{ET}_{\mathrm{B}}$ receptor agonist sarafotoxin $6 \mathrm{c}\left(\mathrm{S} 6 \mathrm{c}, 10^{-7} \mathrm{M}\right)$ compared to fresh SAs 


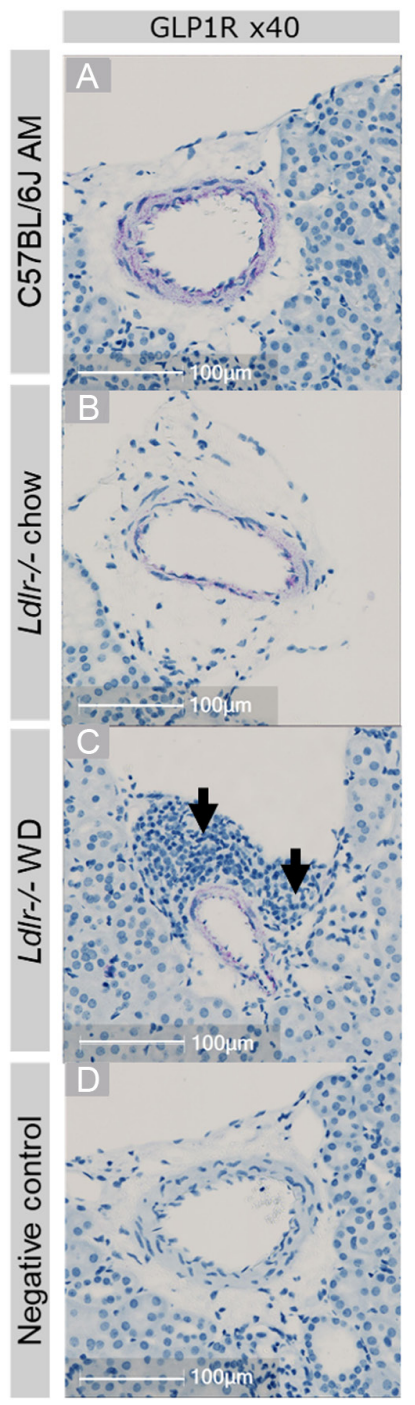

\section{E IHC GLP1R}

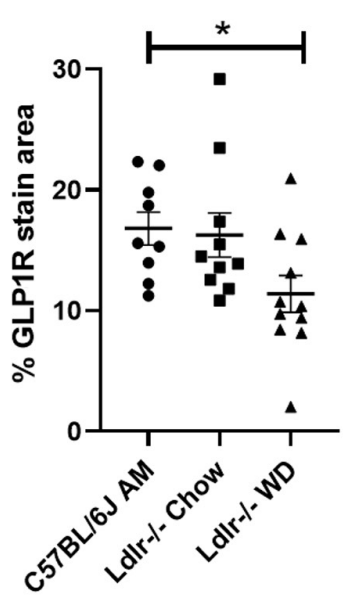

F

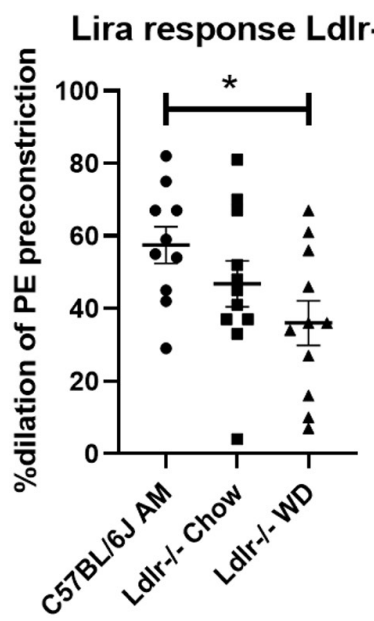

Figure 2

Regulation of the GLP1R in the Ldlr-/- mouse. (A, B and C) Representative images of C57BL/6J AM controls (top row), Ldlr-/- on chow (second row), and LdIr-/- on WD (third row) and negative controls (last row). Arrows point to accumulated inflammatory cells, 40× magnification of GLP1R expression in artery, scale bar $100 \mu \mathrm{m}$. (D) Negative control, no primary antibody. (E) results from IHC image analyses of GLP1R stain area of selected arteries from C57BL/6] AM $(\bullet, n=9)$, Ldlr-/- Chow $(\square, n=10)$, and Ldlr-/- WD $(\boldsymbol{\Lambda}, n=11)$. Data shown as individual values, mean and S.E.M. Kruskal Wallis test and Dunn's multiple comparison test. (F) Response of isolated SA in wire myograph to $10^{-6} \mathrm{M}$ liraglutide from. Data shown as individual values, mean and S.E.M. Ordinary One-way ANOVA, Tukey's multiple comparison test. ${ }^{*} P<0.05 \mathrm{PE}$, phenylephrine; IHC, immunohistochemistry; OC, organ culture; SA, segmental artery; AM, age matched; WD, Western diet.

from WT mice (Fig. 5C). Twenty-four hours organ culture significantly increased the contractile response to S6c in both WT and Glp1r-/- (Fig. 5C, $P<0.0001$ ). Myograph investigation of fresh and organ culture SA showed no significant change in $63 \mathrm{mM} \mathrm{KCl}$ induced constriction of SA in the myograph after organ culture (Fig. 5D).
Organ culture did not affect the contractile response to PE or the passive diameter. There was a significant increase in ET-1 induced constriction $(P=0.0403)$ (Table 3$)$.

\section{Discussion}

The present study shows that the GLP1R specific immunohistochemical signal is decreased in renal arteries of two in vivo mouse models of chronic vascular injury: (i) the NTN model, a renal specific injury model where mice develop kidney damage by an immune-mediated reaction to injected NTS (Ougaard et al. 2018b), and (ii) the Western diet fed Ldlr-/- model, a model of hypercholesterolaemia and atherosclerosis also known to develop prediabetic metabolic disturbances (Ishibashi et al. 1993, Foote et al. 2016). Perivascular accumulation of inflammatory cells in the kidney was present in both models suggesting that inflammation plays a role in the vascular changes reported. Inflammation and renal vascular remodelling are well documented in rodent models of chronic kidney disease (Yuan et al. 2003, Horbelt et al. 2007, Basile et al. 2011, Briet \& Burns 2012, Silva et al. 2019), whereas the Ldlr-/mouse is not commonly known for its renal pathology. Ldlr-/- mice on WD are known to exhibit chronic lowgrade inflammation, which is thought to contribute to the atherosclerotic changes seen in the model (Inoguchi et al. 1992, Foote et al. 2016). Atherosclerosis and metabolic conditions such as elevated cholesterol, obesity, and type two diabetes are known to increase the risk of chronic kidney disease (Carmines 2010). This may be a two-way interaction between vascular disease and kidney disease as moderately uremic (by partial nephrectomy) WD fed Ldlr-/-mice showed increased atherosclerotic burden compared to sham operated controls (Bisgaard et al. 2016). Bisgaard et al. show that liraglutide treatment in moderately uremic mice decrease renal damage and atherosclerosis compared to WT controls. In patients with renal disease increases in atherosclerotic burden has also been reported (Preston et al. 2005, Valdivielso et al. 2019) as has attenuation of renal disease progression by treatment with liraglutide in patients with type 2 diabetes (Mann et al. 2017). This supports the results presented here that GLP1R activation is important for vascular responses to renal injury.

The GLP1R has previously been reported to mediate increased renal flow and perfusion by vasodilatory responses of VSMC associated GLP1R activation (Moreno et al. 2002, Jensen et al. 2015), consistent with the vasodilator response to GLP1R stimulation with 
Table 2 Vasomotor function of SA from Ldlr-/- mice.

\begin{tabular}{|c|c|c|c|}
\hline \multirow[b]{2}{*}{ Response } & & \multicolumn{2}{|r|}{ C57BI/6J } \\
\hline & & $n$ & Mean (S.E.M.) \\
\hline \multirow{4}{*}{$\begin{array}{l}\text { Diameter } \\
\text { KPSS }(63 \mathrm{mM})(\mathrm{mN} / \mathrm{mm}) \\
\text { PE CRC }(\mathrm{mN} / \mathrm{mm})\end{array}$} & $\mu \mathrm{M}$ & 10 & $239(10.4)$ \\
\hline & $E_{\max }$ & 10 & $3.42(0.321)$ \\
\hline & $E_{\max }$ & 10 & $3.74(0.146)$ \\
\hline & $\operatorname{LogEC}_{50}$ & & $-6.88(0.0816)$ \\
\hline \multirow[t]{2}{*}{ Ach CRC (\% dilation) } & $\mathrm{E}_{\max }$ & 10 & $65.5(2.32)$ \\
\hline & $\operatorname{LogEC}_{50}$ & & $-7.18(0.0675)$ \\
\hline \multirow[t]{2}{*}{ SNP CRC (\% dilation) } & $E_{\max }$ & 10 & $80.7(1.80)$ \\
\hline & $\operatorname{LogEC}_{50}$ & 10 & $-7.17(0.0500)$ \\
\hline
\end{tabular}

\begin{tabular}{|c|c|}
\hline \multicolumn{2}{|r|}{ LdIr-/- chow } \\
\hline$n$ & Mean (S.E.M.) \\
\hline 11 & 249 (12.3) \\
\hline 11 & 3.49 (0.459) \\
\hline 11 & $3.85(0.181)$ \\
\hline & $-6.84(0.0958)$ \\
\hline 11 & $63.8(4.70)$ \\
\hline & $-6.83(0.119)$ \\
\hline 11 & $78.5(2.44)$ \\
\hline 11 & $-7.08(0.0746)$ \\
\hline
\end{tabular}

\begin{tabular}{l}
$\frac{n}{11}$ \\
11 \\
11 \\
11 \\
11 \\
11 \\
\hline
\end{tabular}

LdIr-/- WD

Mean (S.E.M.)

$267(13.0)$

$3.28(0.329)$

$3.86(0.167)$

$-6.70(0.0883)$

$73.36(3.30)$

$-6.85(0.0720)$

$77.3(2.49)$

$-7.00(0.0759)$ $\begin{gathered}\text { P-value } \\ \text { (OOW ANOVA) }\end{gathered}$
0.275

0.919

0.972

0.792

0.945

Ach, acetylcholine; CRC, concentration response curve; OOW ANOVA, ordinary one-way analyses of variance; PE, phenylephrine; SNP, sodium nitroprusside.

liraglutide in SA from healthy animals reported in the present study. However, Ronn et al. found an increase in mean arterial pressure, renal blood flow, and natriuresis after infusion of GLP-1 despite the absence of Glp1r in the renal arteries of spontaneously hypertensive rats (Ronn et al. 2017) suggesting that extrarenal GLP-1induced effects, may at least in part be responsible for the blood pressure effects of Glp1r activation in rodents and not directly from GLP-1 mediated vasodilation of
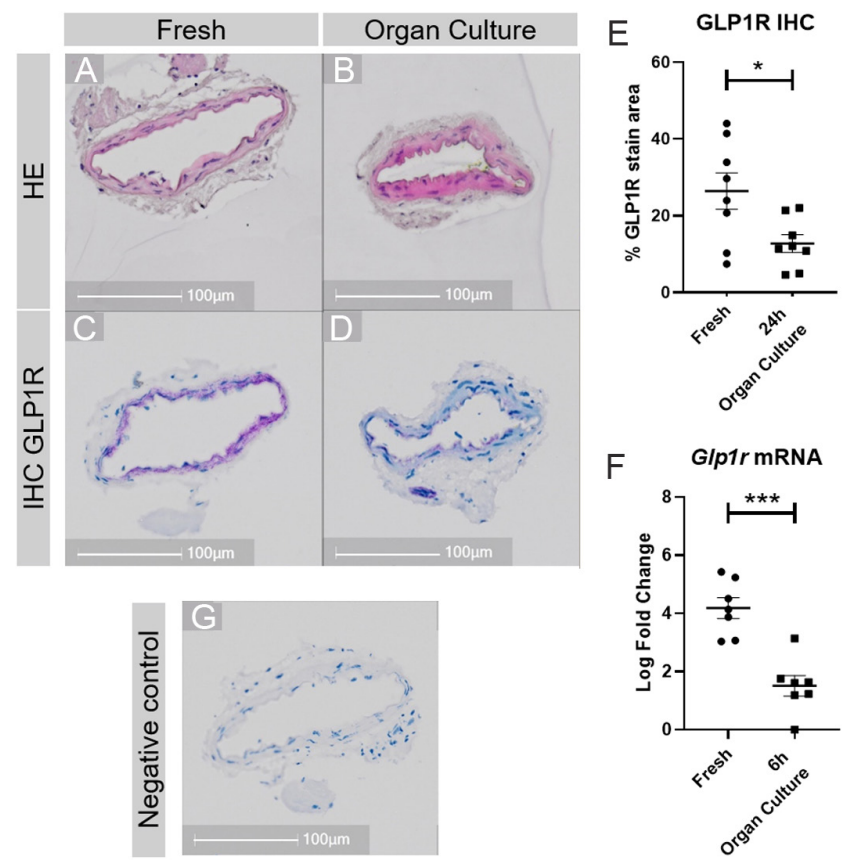

F

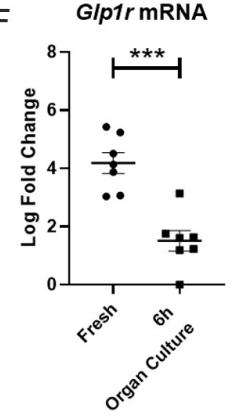

Figure 3

Effect of organ culture on expression of G/p1r. (A) Representative HE stains from fresh $S A,(B)$ representative HE stains of organ culture SA. (C and D) G/p1r IHC stain (purple) in organ culture SA corresponding to HE examples. (E) Results of image analyses of G/p $1 r$ positive stain area from fresh $(\bullet)$ and organ culture $24 \mathrm{~h}(\boldsymbol{\square})$ SA. Paired Student's $t$-test. * $P<0.05$, $\star \star P<0.005$. (F) qPCR results of G/p1r expression from fresh ( $\bullet$ ) and organ culture $6 \mathrm{~h}(\boldsymbol{\square})$ Individual values, mean and S.E.M. Paired Student's $t$-test. (G) Negative control from fresh SA. All images are captured at 40x magnification. Scale bars $100 \mu \mathrm{m}$. IHC, immunohistochemistry. renal arteries. Consequently, it may be speculated that activation of the Glp1r in the renal vasculature promotes other physiological processes important in the healthy kidney, but independent of vasodilation and blood pressure regulation. Previously, it has been shown that GLP-1 treatment has an anti-inflammatory effect, which could be beneficial in clinical and preclinical kidney disease (Hogan et al. 2014, Ougaard et al. 2020). It can be argued that a decrease in renal GLP1R lowers the

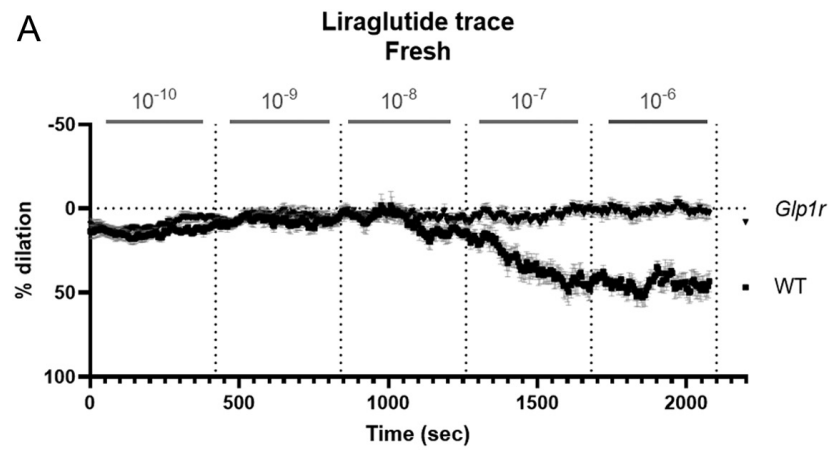

B

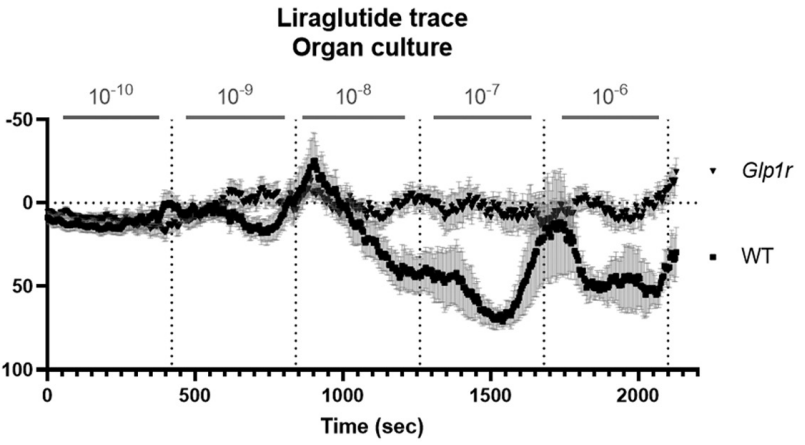

Figure 4

Liraglutide functional response in fresh and organ culture SA from G/p1r-/and WT. (A) Trace graph averaging every $4 \mathrm{~s}$ of the recorded liraglutide response respective to concentration exposure from fresh SA from WT $(\boldsymbol{\square})$ and Glp1r-/- $(\boldsymbol{\nabla})$ mice, data are shown as mean and S.E.M., liraglutide concentration given above. (B) Trace graph of organ cultured SA from WT $(\boldsymbol{\square})$ and G/p1r-/- $(\boldsymbol{\nabla})$ mice, data are shown as mean and S.E.M., liraglutide concentration given above. $\mathrm{PE}$, phenylephrine; Conc., concentration. 
A
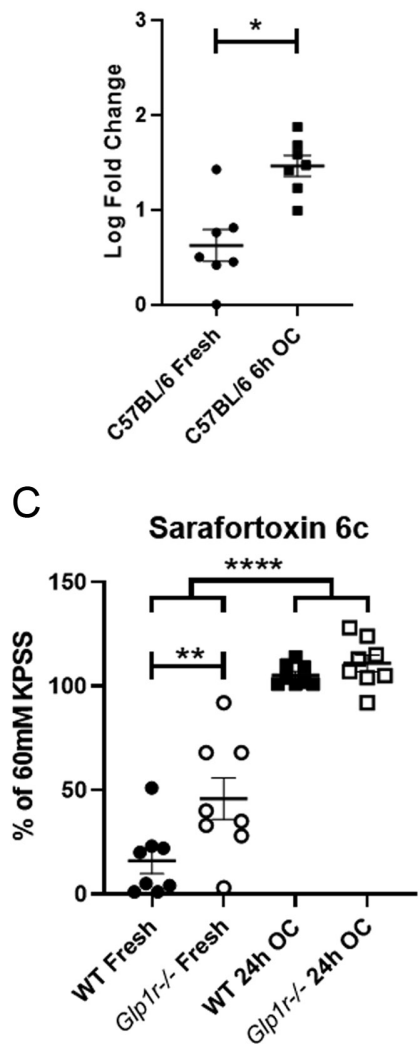
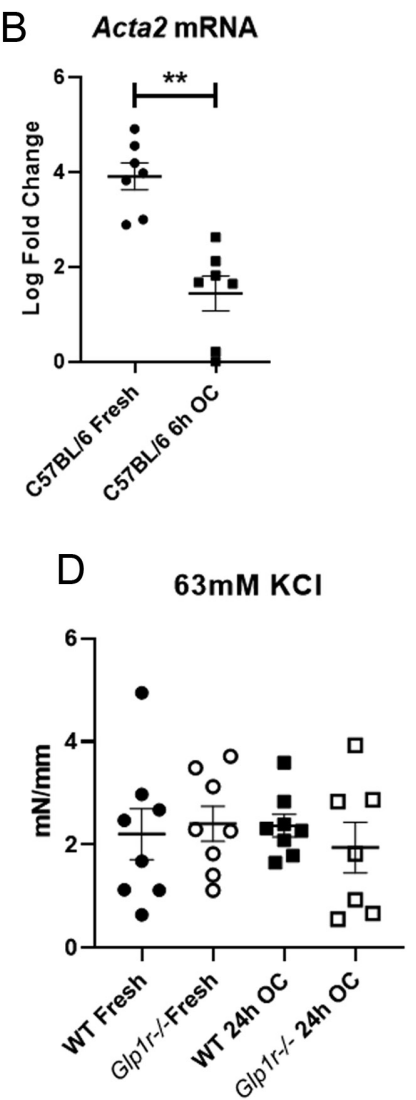

Figure 5

Effect of organ culture on markers of VSMC dedifferentiation and $\mathrm{ET}_{\mathrm{B}}$ receptor response to $\mathrm{S} 6 \mathrm{c}$. (A) $E d n r b$ ( $\mathrm{ET}_{\mathrm{B}}$ receptor) expression from fresh (•) and organ cultured ( $\square$ ) SAs from naïve C57BL/6J mice. Individual values, mean and S.E.M. Wilcoxon paired rank test. (B) Acta2 expression in the same SAs as A. Individual values, mean and S.E.M. Student's $t$-test. (C) Response to $\mathrm{ET}_{\mathrm{B}}$ receptor agonist, sarafotoxin 6c (S6c), in SA from GIp1r-/- and WT littermates (same experiment as Fig. 4). Given as isometric tension relative to last $63 \mathrm{mM} \mathrm{KCl}$ response in myograph protocol. Data are shown as individual values, mean, and S.E.M. Two-way ANOVA, Sidak's multiple comparison. (D) Contractile response to $63 \mathrm{mM}$ $\mathrm{KCl}$ in same vessels as C. Data given as individual values, mean and S.E.M. No difference detected under the two-way ANOVA. SA, segmental artery; S6c, sarafotoxin 6c; WT, wild type; OC, organ culture. * $P<0.05$, $\star \star P<0.005, \star \star \star x P<0.0005$.

protective effect of native GLP-1 on vascular health. The effect is restored by supra-physiological concentrations of GLP1R agonists (such as liraglutide), which activates the remaining GLP1Rs and re-establish the vascular protective effects of GLP1R activation contributing to an overall attenuation of renal disease.

To test if direct vascular injury changes the expression level and vasodilatory function of the GLP1R in the SA, organ culture was used as a model of injury in a system devoid of extravascular injury response mechanisms. Organ culture of the SA from naïve mice induced a rapid decrease ( $6 \mathrm{~h}$ ) in Glp1r mRNA expression, a decrease in the expression of the contractile VSMC specific marker Acta2 and an increase in expression of Endrb coding for the $\mathrm{ET}_{\mathrm{B}}$ receptor. In rats, $\mathrm{ET}_{\mathrm{B}}$ receptors are expressed in kidney VSMCs of afferent arterioles mediating contraction and by endothelial cells of the efferent arteriole mediating vasodilatation, thus playing an important role in maintenance of vascular tone (Inscho et al. 2005). The contractile $\mathrm{ET}_{\mathrm{B}}$ receptor is known to be upregulated in the dedifferentiated VSMC phenotype in vivo after acute vessel injury and in organ culture (Adner et al. 1998, Krawczyk et al. 2018, Skovsted et al. 2019). The time point of $6 \mathrm{~h}$ was based on the rapid reaction of VSMC in organ culture leading to changes in transcription of the $\mathrm{ET}_{\mathrm{B}}$ receptor previously shown in coronary arteries from rats (Skovsted et al. 2012). Twenty-four hours organ culture resulted in a decrease in GLP1R specific immunostaining signal in cultured vessels compared to fresh. Change in the VMSC phenotype was confirmed after $24 \mathrm{~h}$ of culture by an increase in the functional response to the specific $\mathrm{ET}_{\mathrm{B}}$ receptor agonist S6c in cultured vessels compared to fresh. Twenty hours were chosen for investigation of protein levels by immunohistochemistry to allow for the rapid transcriptional change to manifest in protein level expression and in functional responses.

Table 3 Vasomotor function in fresh and organ cultured vessels from naïve mice.

\begin{tabular}{|c|c|c|c|c|c|c|}
\hline \multirow[b]{2}{*}{ Response } & & \multicolumn{2}{|c|}{ Fresh } & \multicolumn{2}{|c|}{ Organ culture } & \multirow[b]{2}{*}{$\boldsymbol{P}$-value ( $t$-test, fresh vs organ culture) } \\
\hline & & $n$ & Mean (S.E.M.) & $n$ & Mean (S.E.M.) & \\
\hline Diameter $(\mu \mathrm{m})$ & & 19 & $210(31.3)$ & 23 & $227(30.5)$ & 0.121 \\
\hline $\mathrm{KCl}(63 \mathrm{mM})(\mathrm{mN} / \mathrm{mm})$ & $\mathrm{E}_{\max }$ & 19 & $1.91(0.252)$ & 23 & $1.76(0.209)$ & 0.696 \\
\hline $\mathrm{PE}\left(10^{-5} \mathrm{M}\right)$ & $\mathrm{E}_{\max }$ & 10 & $2.27(0.329)$ & 13 & $1.99(0.235)$ & 0.441 \\
\hline ET-1 (10-7 M) (mN/mm) & $\mathrm{E}_{\max }$ & 5 & $1.41(0.254)$ & 7 & $2.11(0.317)$ & $0.0403^{*}$ \\
\hline
\end{tabular}

Significant $P$-values are emphasized in bold.

$\star P<0.05$.

Ach, acetylcholine; CRC, concentration response curve; PE, phenylephrine; SNP, sodium nitroprusside.

https://joe.bioscientifica.com

https://doi.org/10.1530/JOE-20-0608 (c) 2021 Society for Endocrinology Published by Bioscientifica Ltd. Printed in Great Britain 
Data from all three models of SA artery injury suggest that GLP1R expression is connected to VSMC phenotype and vascular inflammation. Chronic vascular disease such as atherosclerosis has been shown to activate the protein-kinase $\mathrm{C}$ beta (PKC $\beta$ ) pathway in response to signals including, but not limited to, upregulation of intercellular adhesion molecule-1 (ICAM-1) and vascular cell adhesion molecule-1 (VCAM-1) in the activated endothelium as well as inflammatory cytokines such as TNFo leading to downstream release of growth factors ultimately resulting in VSMC activation and dedifferentiation (Yan et al. 2006, Kong et al. 2013). Interestingly, the same pathway has been suggested to downregulate the GLP1R in spontaneously hypertensive rats (Liu et al. 2015, Ronn et al. 2017). The VSMC of resistance and conductance arteries from spontaneously hypertensive rats are known to show signs of remodelling and dedifferentiation (Owens et al. 1988, Berk et al. 1989), which may contribute to arterial stiffening (Hays et al. 2018). Moreover, VSMC from spontaneously hypertensive rats have been have increased expression and activity to protein-Kinase C activation (Silver et al. 1988, Peng et al. 2007), a pathway that is common for inflammatory vascular conditions. Hence, further investigations are warranted to confirm the role of inflammatory pathways in injuryinduced GLP1R regulation in the SA.

Alternatively, the connecting pathway between GLP1R expression and VSMC phenotypic switch may involve the transcription factor TCF7L2. In the healthy vessel TCF7L2 activated by Wnt/LRP6 signalling on the VSMCs and confers the maintenance of the VSMC in a contractile state (Srivastava et al. 2015, 2019). In the injured vessel Wnt/LRP6 signalling is impaired which leads to activation of transcription factor SP1 resulting in VSMC phenotypic switching (Srivastava et al. 2015). Interestingly, Kimura et al. showed that TCF7L2 is also involved in GLP1R downregulation in VSCM in diabetic mice (Kimura et al. 2017). Considering this in light of the present data it could be speculated that the decrease in GLP1R expression in SA during vascular injury is causally linked to VSMC dedifferentiation mediated by a common transcriptional pathway involving TCF7L2. The fact that fresh SA from Glp1r-/- mice show an increased response to the $\mathrm{ET}_{\mathrm{B}}$ receptor agonist $\mathrm{S6c}$ supports that GLP1R signalling is indeed involved in the regulation of VSMC phenotype, albeit more investigations are necessary to establish the precise causal relationship.

In agreement with findings with native GLP-1 (Jensen et al. 2020), this study shows that liraglutide results in a receptor-mediated dilatory response in the SA of $L d l r-/-$ mice and naïve C57BL/6J mice. Chronic vascular injury decreased the dilatory response to liraglutide in the wire myograph investigation of the SA from Ldlr-/- mouse on WD despite that there were no changes in the SA response to the other vasodilators Ach and SNP.

Based on the present results from NTN and Ldlr-/mice it cannot be concluded if the decreased GLP1R specific IHC signal is due to a downregulation of receptor expression or increased receptor activity and subsequent internalization and degradation. The GLP1R is a G-protein coupled receptor located on the membrane, which is expected to be internalized following activation, and subsequently degraded following betaarrestin activation (Jones et al. 2018). As beta-arrestin is activated by cAMP levels (Parruti et al. 1993), and these are known to be decreased during vascular damage for example, by increase in phosphodiesterase activity (Priksz et al. 2018), it may be speculated that a decrease in beta-arrestin could mediate an impaired GLP1R de-sensitization resulting in maintained function during acute downregulation of the GLP1R.

The present work is a collection of data from three models representing three different mouse strains (CD1, Ldlr-/-, C57BL/6J, and Glp1r-/-) and also both female (NTN) and male (Ldlr-/-, C57BL/6J, and Glp1r-/-) mice under different housing conditions. Furthermore, three different methods of disease induction are included challenging the direct translation between magnitude of response in the different models. Thus, the main conclusion from the findings in this study is that the three different disease paradigms all lead to a significantly lower GLP1R signal suggestive of a qualitative change in GLP1R expression across a range of different renal vascular injury models.

\section{Conclusions}

The present report shows that mouse models of nephrotoxic nephritis and atherosclerosis lead to a decrease in GLP1R specific immunohistochemical signal. In the atherosclerotic $L d l r-/-$ mouse on WD also showed a decrease in dilatory response to liraglutide. The organ culture model mimicking acute vascular injury ex vivo led to a decrease in expression of Glp1r and contractile VSMC specific markers and increase in expression of dedifferentiation markers. The response to the ETB receptor specific agonist S6c was greater in Glp1r-/compared to WT littermate controls suggestive of an 
relationship between phenotypic swich of the VSMC and the expression of the GLP1R however, the causal relationship remains elusive.

\section{Supplementary materials}

This is linked to the online version of the paper at https://doi.org/10.1530/ JOE-20-0608.

\section{Declaration of interest}

G K P, M E O, G R, and C P are employees of Novo Nordisk A/S that produces liraglutide. The remaining authors are employed by University of Copenhagen and have collaborated with Novo Nordisk on the present project.

\section{Funding}

This study was partly funded by Novo Nordisk A/S and the LifePharm Center for In Vivo Pharmacology at University of Copenhagen.

\section{Acknowledgements}

Bettina Brandrup is thanked for excellent technical assistance; Jonas Ahnfelt-Rønne is thanked for helpful discussions of data and help with image analysis.

\section{References}

Adner M, Uddman E, Cardell LO \& Edvinsson L 1998 Regional variation in appearance of vascular contractile endothelin-B receptors following organ culture. Cardiovascular Research 37 254-262. (https://doi. org/10.1016/s0008-6363(97)00206-x)

Alscher MD, Erley C \& Kuhlmann MK 2019 Acute renal failure of nosocomial origin. Deutsches Ärzteblatt International 116 149-158. (https://doi.org/10.3238/arztebl.2019.0149)

Basile DP, Friedrich JL, Spahic J, Knipe N, Mang H, Leonard EC, ChangiziAshtiyani S, Bacallao RL, Molitoris BA \& Sutton TA 2011 Impaired endothelial proliferation and mesenchymal transition contribute to vascular rarefaction following acute kidney injury. American Journal of Physiology: Renal Physiology 300 F721-F733. (https://doi.org/10.1152/ ajprenal.00546.2010)

Berk B, Vallega G, Muslin AJ, Gordon H, Canessa M \& Alexander RJT 1989 Spontaneously hypertensive rat vascular smooth muscle cells in culture exhibit increased growth and $\mathrm{Na}+\mathrm{H}+$ exchange. Journal of Clinical Investigation 83 822-829. (https://doi.org/10.1172/JCI113964)

Bisgaard LS, Bosteen MH, Fink LN, Sorensen CM, Rosendahl A, Mogensen CK, Rasmussen SE, Rolin B, Nielsen LB \& Pedersen TX 2016 Liraglutide reduces both atherosclerosis and kidney inflammation in moderately uremic LDLr-/- mice (Research Article) (Report). PLoS ONE 11 e0168396. (https://doi.org/10.1371/journal.pone.0168396)

Bjørnholm KD, Skovsted GF, Mitgaard-Thomsen A, Rakipovski G, Tveden-Nyborg P, Lykkesfeldt J \& Povlsen GK 2020 Liraglutide treatment improves endothelial function in the Ldlr-/- mouse model of atherosclerosis, and affects genes involved in vascular remodelling and inflammation. Basic and Clinical Pharmacology and Toxicology $\mathbf{1 2 8}$ 103-114. (https://doi.org/10.1111/bcpt.13486)
Briet M \& Burns KD 2012 Chronic kidney disease and vascular remodelling: molecular mechanisms and clinical implications. Clinical Science 123 399-416. (https://doi.org/10.1042/CS20120074)

Carmines PK 2010 The renal vascular response to diabetes. Current Opinion in Nephrology and Hypertension 19 85-90. (https://doi. $\operatorname{org} / 10.1097 / \mathrm{MNH} .0 \mathrm{~b} 013 \mathrm{e} 32833240 \mathrm{fc})$

Chawla LS \& Kimmel PL 2012 Acute kidney injury and chronic kidney disease: an integrated clinical syndrome. Kidney International $\mathbf{8 2}$ 516-524. (https://doi.org/10.1038/ki.2012.208)

Choi YJ, Chakraborty S, Nguyen V, Nguyen C, Kim BK, Shim SI, Suki WN \& Truong LD 2000 Peritubular capillary loss is associated with chronic tubulointerstitial injury in human kidney: altered expression of vascular endothelial growth factor. Human Pathology 31 1491-1497. (https://doi.org/10.1053/hupa.2000.20373)

De Mey JG, Uitendaal MP, Boonen HC, Vrijdag MJ, Daemen MJ \& Struyker-Boudier HA 1989 Acute and long-term effects of tissue culture on contractile reactivity in renal arteries of the rat. Circulation Research 65 1125-1135. (https://doi.org/10.1161/01.res.65.4.1125)

Doyle ME \& Egan JM 2007 Mechanisms of action of GLP-1 in the pancreas. Pharmacology and Therapeutics 113 546-593. (https://doi. org/10.1016/j.pharmthera.2006.11.007)

Eberhardt W \& Pfeilschifter J 2007 Nitric oxide and vascular remodeling: spotlight on the kidney. Kidney International: Supplement 106 S9-S16. (https://doi.org/10.1038/sj.ki.5002381)

Foote CA, Castorena-Gonzalez JA, Ramirez-Perez FI, Jia G, Hill MA, ReyesAldasoro CC, Sowers JR \& Martinez-Lemus LA 2016 Arterial stiffening in western diet-fed mice is associated with increased vascular elastin, transforming growth factor- $\beta$, and plasma neuraminidase. Frontiers in Physiology 7 285. (https://doi.org/10.3389/fphys.2016.00285)

Fujita H, Morii T, Fujishima H, Sato T, Shimizu T, Hosoba M, Tsukiyama K, Narita T, Takahashi T, Drucker DJ, et al. 2014 The protective roles of GLP-1R signaling in diabetic nephropathy: possible mechanism and therapeutic potential. Kidney International $\mathbf{8 5}$ 579-589. (https://doi.org/10.1038/ki.2013.427)

Hays TT, Ma B, Zhou N, Stoll S, Pearce WJ \& Qiu H 2018 Vascular smooth muscle cells direct extracellular dysregulation in aortic stiffening of hypertensive rats. Aging Cell 17 e12748. (https://doi.org/10.1111/ acel.12748)

Hogan AE, Gaoatswe G, Lynch L, Corrigan MA, Woods C, O'Connell J \& O'Shea D 2014 Glucagon-like peptide 1 analogue therapy directly modulates innate immune-mediated inflammation in individuals with type 2 diabetes mellitus. Diabetologia 57 781-784. (https://doi. org/10.1007/s00125-013-3145-0)

Holst JJ 2007 The physiology of glucagon-like peptide 1. Physiological Reviews 87 1409-1439. (https://doi.org/10.1152/physrev.00034.2006)

Horbelt M, Lee SY, Mang HE, Knipe NL, Sado Y, Kribben A \& Sutton TA 2007 Acute and chronic microvascular alterations in a mouse model of ischemic acute kidney injury. American Journal of Physiology: Renal Physiology 293 F688-F695. (https://doi.org/10.1152/ ajprenal.00452.2006)

Humphreys BD, Lin SL, Kobayashi A, Hudson TE, Nowlin BT, Bonventre JV, Valerius MT, McMahon AP \& Duffield JS 2010 Fate tracing reveals the pericyte and not epithelial origin of myofibroblasts in kidney fibrosis. American Journal of Pathology 176 85-97. (https:// doi.org/10.2353/ajpath.2010.090517)

Inoguchi T, Battan R, Handler E, Sportsman JR, Heath W \& King GL 1992 Preferential elevation of protein kinase C isoform beta II and diacylglycerol levels in the aorta and heart of diabetic rats: differential reversibility to glycemic control by islet cell transplantation. PNAS $\mathbf{8 9}$ 11059-11063. (https://doi.org/10.1073/pnas.89.22.11059)

Inscho EW, Imig JD, Cook AK \& Pollock DM 2005 ETA and ETB receptors differentially modulate afferent and efferent arteriolar responses to endothelin. British Journal of Pharmacology 146 1019-1026. (https:// doi.org/10.1038/sj.bjp.0706412)

Ishibashi S, Brown MS, Goldstein JL, Gerard RD, Hammer RE \& Herz J 1993 Hypercholesterolemia in low density lipoprotein receptor https://joe.bioscientifica.com

https://doi.org/10.1530/JOE-20-0608
(C) 2021 Society for Endocrinology Published by Bioscientifica Ltd. Printed in Great Britain 
knockout mice and its reversal by adenovirus-mediated gene delivery Journal of Clinical Investigation 92 883-893. (https://doi.org/10.1172/ JCI116663)

Jensen EP, Poulsen SS, Kissow H, Holstein-Rathlou NH, Deacon CF, Jensen BL, Holst JJ \& Sorensen CM 2015 Activation of GLP-1 receptors on vascular smooth muscle cells reduces the autoregulatory response in afferent arterioles and increases renal blood flow. American Journal of Physiology: Renal Physiology 308 F867-F877. (https://doi. org/10.1152/ajprenal.00527.2014)

Jensen EP, Møller S, Hviid AVR, Veedfald S, Holst JJ, Pedersen J, Ørskov C \& Sorensen CM 2020 GLP-1-induced renal vasodilation in rodents depends exclusively on the known GLP-1 receptor and is lost in prehypertensive rats. American Journal of Physiology: Renal Physiology 318 F1409-F1417. (https://doi.org/10.1152/ajprenal.00579.2019)

Jones B, Buenaventura T, Kanda N, Chabosseau P, Owen BM, Scott R, Goldin R, Angkathunyakul N, Corrêa Jr IR, Bosco D, et al. 2018 Targeting GLP-1 receptor trafficking to improve agonist efficacy. Nature Communications 9 1602. (https://doi.org/10.1038/s41467-018-03941-2)

Katsurada K, Nandi SS, Sharma NM, Zheng H, Liu X \& Patel KP 2019 Does glucagon-like peptide-1 induce diuresis and natriuresis by modulating afferent renal nerve activity? American Journal of Physiology: Renal Physiology 317 F1010-F1021. (https://doi.org/10.1152/ ajprenal.00028.2019)

Kimura T, Obata A, Shimoda M, Okauchi S, Hirukawa H, Kohara K, Kinoshita T, Nogami Y, Nakanishi S, Mune T, et al. 2017 Decreased glucagon-like peptide 1 receptor expression in endothelial and smooth muscle cells in diabetic $\mathrm{db} / \mathrm{db}$ mice: TCF7L2 is a possible regulator of the vascular glucagon-like peptide 1 receptor. Diabetes and Vascular Disease Research 14 540-548. (https://doi. org/10.1177/1479164117725898)

Koelzer VH, Gisler A, Hanhart JC, Griss J, Wagner SN, Willi N, Cathomas G, Sachs M, Kempf W, Thommen DS, et al. 2018 Digital image analysis improves precision of PD-L1 scoring in cutaneous melanoma. Histopathology 73 397-406. (https://doi.org/10.1111/his.13528)

Kong L, Shen X, Lin L, Leitges M, Rosario R, Zou YS \& Yan SF 2013 PKCbeta promotes vascular inflammation and acceleration of atherosclerosis in diabetic ApoE null mice. Arteriosclerosis, Thrombosis, and Vascular Biology 33 1779-1787. (https://doi.org/10.1161/ ATVBAHA.112.301113)

Korner M, Stockli M, Waser B \& Reubi JC 2007 GLP-1 receptor expression in human tumors and human normal tissues: potential for in vivo targeting. Journal of Nuclear Medicine 48 736-743. (https://doi. org/10.2967/jnumed.106.038679)

Krawczyk KK, Skovsted GF, Perisic L, Dreier R, Berg JO, Hedin U, Rippe C \& Sward K 2018 Expression of endothelin type B receptors (EDNRB) on smooth muscle cells is controlled by MKL2, ternary complex factors, and actin dynamics. American Journal of Physiology: Cell Physiology 315 C873-C884. (https://doi.org/10.1152/ ajpcell.00170.2018)

Liu L, Liu J, Gao Y, Ng CF, Yu X, Dou D \& Huang Y 2015 Protein kinase Cbeta mediates downregulated expression of glucagon-like peptide-1 receptor in hypertensive rat renal arteries. Journal of Hypertension 33 784-790. (https://doi.org/10.1097/HJH.0000000000000480)

Luyckx VA, Tonelli M \& Stanifer JW 2018 The global burden of kidney disease and the sustainable development goals. Bulletin of the World Health Organization 96 414-422D. (https://doi.org/10.2471/ BLT.17.206441)

Ma Y, Wang W, Zhang J, Lu Y, Wu W, Yan H \& Wang Y 2012 Hyperlipidemia and atherosclerotic lesion development in Ldlrdeficient mice on a long-term high-fat diet. PLoS ONE 7 e35835. (https://doi.org/10.1371/journal.pone.0035835)

Mann JFE, Orsted DD, Brown-Frandsen K, Marso SP, Poulter NR, Rasmussen S, Tornoe K, Zinman B, Buse JB \& Committee LS 2017 Liraglutide and renal outcomes in Type 2 diabetes. New England Journal of Medicine 377 839-848. (https://doi.org/10.1056/ NEJMoa1616011)
Marso SP, Bain SC, Consoli A, Eliaschewitz FG, Jódar E, Leiter LA, Lingvay I, Rosenstock J, Seufert J, Warren ML, et al. $2016 a$ Semaglutide and cardiovascular outcomes in patients with Type 2 diabetes. New England Journal of Medicine 375 1834-1844. (https://doi. org/10.1056/NEJMoa1607141)

Marso SP, Daniels GH, Brown-Frandsen K, Kristensen P, Mann JF, Nauck MA, Nissen SE, Pocock S, Poulter NR, Ravn LS, et al. $2016 b$ Liraglutide and cardiovascular outcomes in Type 2 diabetes. New England Journal of Medicine 375 311-322. (https://doi.org/10.1056/ NEJMoa1603827)

Moreno C, Mistry M \& Roman RJ 2002 Renal effects of glucagon-like peptide in rats. European Journal of Pharmacology 434 163-167. (https://doi.org/10.1016/s0014-2999(01)01542-4)

Motulsky HJ \& Brown RE 2006 Detecting outliers when fitting data with nonlinear regression - a new method based on robust nonlinear regression and the false discovery rate. BMC Bioinformatics 7123 . (https://doi.org/10.1186/1471-2105-7-123)

Ougaard ME, Jensen HE, Thuen ID, Petersen EG \& Kvist PH $2018 a$ Inhibitors of the renin-angiotensin system ameliorates clinical and pathological aspects of experimentally induced nephrotoxic serum nephritis. Renal Failure 40 640-648. (https://doi.org/10.1080/08860 22X.2018.1533867)

Ougaard MKE, Kvist PH, Jensen HE, Hess C, Rune I \& Søndergaard H $2018 b$ Murine nephrotoxic nephritis as a model of chronic kidney disease. International Journal of Nephrology 2018 8424502. (https://doi. org/10.1155/2018/8424502)

Ougaard ME, Sembach FE, Jensen HE, Pyke C, Knudsen LB \& Kvist PH 2020 Liraglutide improves the kidney function in a murine model of chronic kidney disease. Nephron 144 595-606. (https://doi. org/10.1159/000509418)

Owens GK, Schwartz SM \& McCanna M 1988 Evaluation of medial hypertrophy in resistance vessels of spontaneously hypertensive rats 11. Hypertension 11 198-207. (https://doi.org/10.1161/01. hyp.11.2.198)

Parruti G, Peracchia F, Sallese M, Ambrosini G, Masini M, Rotilio D \& De Blasi A 1993 Molecular analysis of human beta-arrestin-1: cloning, tissue distribution, and regulation of expression. Identification of two isoforms generated by alternative splicing. Journal of Biological Chemistry 268 9753-9761. (https://doi.org/10.1016/S0021-9258(18)98412-7)

Peng Z, Dang A \& Arendshorst WJ 2007 Increased expression and activity of phospholipase $\mathrm{C}$ in renal arterioles of young spontaneously hypertensive rats. American Journal of Hypertension 20 38-43. (https:// doi.org/10.1016/j.amjhyper.2006.06.009)

Preston E, Ellis MR, Kulinskaya E, Davies AH \& Brown EA 2005 Association between carotid artery intima-media thickness and cardiovascular risk factors in CKD. American Journal of Kidney Diseases 46 856-862. (https://doi.org/10.1053/j.ajkd.2005.07.048)

Priksz D, Bombicz M, Varga B, Kurucz A, Gesztelyi R, Balla J, Toth A, Papp Z, Szilvassy Z \& Juhasz B 2018 Upregulation of myocardial and vascular phosphodiesterase $9 \mathrm{~A}$ in A model of atherosclerotic cardiovascular disease. International Journal of Molecular Sciences 19 2882. (https://doi.org/10.3390/ijms19102882)

Pyke C, Heller RS, Kirk RK, Ørskov C, Reedtz-Runge S, Kaastrup P, Hvelplund A, Bardram L, Calatayud D \& Knudsen LB 2014 GLP-1 receptor localization in monkey and human tissue: novel distribution revealed with extensively validated monoclonal antibody. Endocrinology 155 1280-1290. (https://doi.org/10.1210/en.2013-1934)

Richards P, Parker HE, Adriaenssens AE, Hodgson JM, Cork SC, Trapp S, Gribble FM \& Reimann F 2014 Identification and characterization of GLP-1 receptor-expressing cells using a new transgenic mouse model. Diabetes 63 1224-1233. (https://doi.org/10.2337/db13-1440)

Ronn J, Jensen EP, Wewer Albrechtsen NJ, Holst JJ \& Sorensen CM 2017 Glucagon-like peptide-1 acutely affects renal blood flow and urinary flow rate in spontaneously hypertensive rats despite significantly reduced renal expression of GLP-1 receptors. Physiological Reports 5 e13503. (https://doi.org/10.14814/phy2.13503) https://joe.bioscientifica.com

https://doi.org/10.1530/JOE-20-0608 (c) 2021 Society for Endocrinology Published by Bioscientifica Ltd. Printed in Great Britain 
Scrocchi LA, Brown TJ, Maclusky N, Brubaker PL, Auerbach AB, Joyner AL \& Drucker DJ 1996 Glucose intolerance but normal satiety in mice with a null mutation in the glucagon-like peptide 1 receptor gene. Nature Medicine 2 1254-1258. (https://doi.org/10.1038/nm1196-1254)

Shah M \& Vella A 2014 Effects of GLP-1 on appetite and weight. Reviews in Endocrine and Metabolic Disorders 15 181-187. (https://doi. org/10.1007/s11154-014-9289-5)

Silva EH, Wickramatilake CM, Lekamwasam S, Mudduwa LKB \& Ubayasiri RA 2019 Vascular dysfunction and atherosclerosis in chronic kidney disease: a distinct entity. Journal of Nephropathology $\mathbf{8}$ 17-17. (https://doi.org/10.15171/jnp.2019.17)

Silver PJ, Lepore RE, Cumiskey WR, Kiefer D \& Harris AL 1988 Protein kinase $\mathrm{C}$ activity and reactivity to phorbol ester in vascular smooth muscle from spontaneously hypertensive rats (SHR) and normotensive Wistar Kyoto rats (WKY). Biochemical and Biophysical Research Communications 154 272-277. (https://doi.org/10.1016/0006$291 \mathrm{x}(88) 90680-8)$

Skov J, Dejgaard A, Frøkiær J, Holst JJ, Jonassen T, Rittig S \& Christiansen JS 2013 Glucagon-like peptide-1 (GLP-1): effect on kidney hemodynamics and renin-angiotensin-aldosterone system in healthy men. Journal of Clinical Endocrinology and Metabolism 98 E664-E671. (https://doi.org/10.1210/jc.2012-3855)

Skovsted GF, Pedersen AF, Larsen R, Sheykhzade M \& Edvinsson L 2012 Rapid functional upregulation of vasocontractile endothelin ETB receptors in rat coronary arteries. Life Sciences 91 593-599. (https:// doi.org/10.1016/j.lfs.2012.02.009)

Skovsted GF, Tveden-Nyborg P \& Lykkesfeldt J 2019 Expression of endothelin type B receptors in uterine artery smooth muscle cells from pregnant Guinea pigs. Placenta 77 8-15. (https://doi. org/10.1016/j.placenta.2019.01.015)

Srivastava R, Zhang J, Go GW, Narayanan A, Nottoli TP \& Mani A 2015 Impaired LRP6-TCF7L2 activity enhances smooth muscle cell plasticity and causes coronary artery disease. Cell Reports 13 746-759. (https://doi.org/10.1016/j.celrep.2015.09.028)

Srivastava R, Rolyan H, Xie Y, Li N, Bhat N, Hong L, Esteghamat F, Adeniran A, Geirsson A, Zhang J, et al. 2019 TCF7L2 (transcription factor 7-like 2) regulation of GATA6 (GATA-binding Protein 6)-dependent and -independent vascular smooth muscle cell plasticity and intimal hyperplasia. Arteriosclerosis, Thrombosis, and Vascular Biology 39 250-262. (https://doi.org/10.1161/ ATVBAHA.118.311830)

Thomas MC 2017 The potential and pitfalls of GLP-1 receptor agonists for renal protection in type 2 diabetes. Diabetes and Metabolism 43 (Supplement 1) 2S20-2S27. (https://doi.org/10.1016/S12623636(17)30069-1)

Valdivielso JM, Rodriguez-Puyol D, Pascual J, Barrios C, BermudezLopez M, Sanchez-Nino MD, Perez-Fernandez M \& Ortiz A 2019 Atherosclerosis in chronic kidney disease: more, less, or just different? Arteriosclerosis, Thrombosis, and Vascular Biology 39 1938-1966. (https://doi.org/10.1161/ATVBAHA.119.312705)

Yan SF, Harja E, Andrassy M, Fujita T \& Schmidt AM 2006 Protein kinase $\mathrm{C} \beta$ /early growth response- 1 pathway. Journal of the American College of Cardiology 48 (Supplement 1) A47-A55. (https://doi.org/10.1016/j. jacc.2006.05.063)

Yu M, Moreno C, Hoagland KM, Dahly A, Ditter K, Mistry M \& Roman RJ 2003 Antihypertensive effect of glucagon-like peptide 1 in Dahl salt-sensitive rats. Journal of Hypertension 21 1125-1135. (https://doi. org/10.1097/00004872-200306000-00012)

Yuan HT, Li XZ, Pitera JE, Long DA \& Woolf AS 2003 Peritubular capillary loss after mouse acute nephrotoxicity correlates with down-regulation of vascular endothelial growth factor-A and hypoxia-inducible factor-1 alpha. American Journal of Pathology 163 2289-2301. (https://doi.org/10.1016/s00029440(10)63586-9)

Received in final form 4 December 2020

Accepted 5 January 2021

Accepted Manuscript published online 8 January 2021
(C) 2021 Society for Endocrinology Published by Bioscientifica Ltd.
Printed in Great Britain 